\title{
The Lower Palaeozoic shale gas play in Denmark
}

\author{
Niels H. Schovsbo, Arne T. Nielsen and Donald L. Gautier
}

The unconventional gas resources in the Lower Palaeozoic shale of Denmark were recently assessed by the United States Geological Survey (USGS; Gautier et al. 2013). Assuming unrestricted application of best practice current technology, recoverable gas resources of 0 to $130 \times 10^{9} \mathrm{Nm}^{3}$ gas were estimated onshore $\left(\right.$ mean $=67 \times 10^{9} \mathrm{Nm}^{3}$ gas $)$ and 0 to $228 \times$ $10^{9} \mathrm{Nm}^{3}$ gas were estimated offshore $\left(\right.$ mean $=119 \times 10^{9} \mathrm{Nm}^{3}$ gas), i.e. a total estimated mean of $186 \times 10^{9} \mathrm{Nm}^{3}$ gas $\left(\mathrm{Nm}^{3}\right.$ : normal cubic metre, unit used for natural gas at $0^{\circ} \mathrm{C}$ and $101.325 \mathrm{kPa}$ ). Nearly all of this potential resource is assumed to be contained in the Cambro-Ordovician Alum Shale. The wide range of estimates reflects the sparse data and the geological uncertainty inherent in the still untested play. The estimated mean quantity of gas resource is comparable to the total volume of gas produced from the Danish part of the North Sea during 1972-2011 and twice the amount of the estimated remaining reserves of conventional gas in the Danish part of the North Sea.

The assessment is the result of collaboration between The Geological Survey of Denmark and Greenland (GEUS) and USGS. GEUS and the University of Copenhagen contributed with the geological input data and models and USGS provided assessment methodology and North American resource analogues. In this paper the geological model that underlies the assessment is presented along with some additional considerations on the nature of the play. Details and methodology of the assessment itself were summarised by Gautier et al. (2013).

\section{The Danish shale gas play}

Shale gas is an unconventional energy resource in which gas is produced directly from a shale source rock. Highly productive formations in North America are regionally extensive, tens of metres thick, highly organic-rich, and have been buried sufficiently to reach the temperatures necessary for thermal gas generation. The technique of using horizontal drilling and hydraulic fracturing to extract gas from shale was developed in North America, where it has had a significant impact on gas markets. Application of this technology has not yet led to shale gas production in Europe. The first shale gas exploration borehole in Denmark, the Vendsyssel-1, is due to be drilled in northern Jylland in 2015 by the company Total E\&P (Fig. 1).

Since 2009, GEUS has conducted a wide range of shale gas evaluation programmes including screening of onshore Denmark for potential shale gas units. The evaluation is partly based on extensive shallow coring on Bornholm where the shale is accessible immediately beneath a thin Quaternary cover (Schovsbo et al. 2011). The main target for exploration in Denmark is the Alum Shale Formation, which is up to $180 \mathrm{~m}$ thick and unusually rich in organic matter, typically with 5-10\% total organic carbon (TOC; Schovsbo et al. 2011). Organic-rich shales also occur in younger OrdovicianSilurian successions. These black shales are thinner and less TOC-rich than the Alum Shale, but may still be interesting for shale gas exploration.

\section{Thermal modelling}

The Terne-1 borehole, drilled in Kattegat in 1985 (Fig. 1), penetrated a $180 \mathrm{~m}$ thick Alum Shale Formation and is a

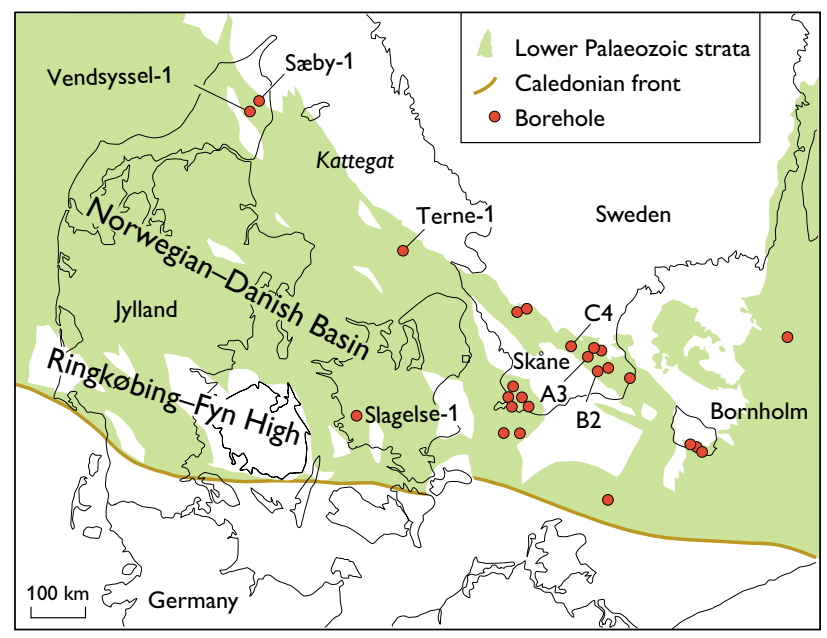

Fig. 1. Map showing simplified distribution of Lower Palaeozoic strata in Denmark and the location of scientific and exploration boreholes used for the geological assessment. The position of the planned Vendsyssel-1 borehole is also shown. In all boreholes made so far in Denmark and Skåne, the Alum Shale is mature to gas rank and positioned beneath a Palaeozoic sequence less than $1 \mathrm{~km}$ thick; at these sites the shale did not contain significant amounts of gas. The distribution of Lower Palaeozoic strata is from Nielsen \& Schovsbo (2011). 
key borehole for shale gas exploration in Denmark. Thermal modelling of Terne-1 was carried out to calibrate the burial history and maturation profiles. The Alum Shale contains a marine type II kerogen that yields lighter hydrocarbons on maturation than typical type II kerogen. Maturity gradients were constructed by converting the reflectance values of vitrinite-like particles to vitrinite-equivalent values following Petersen et al. (2013) since vitrinite-like particles in the Alum Shale mature at lower temperatures than true vitrinite.

The modelling showed that the Lower Palaeozoic shales were buried within a Caledonian foreland basin and that large volumes of oil were probably generated during the Silurian (Gautier et al. 2013). In most areas, kerogen subsequently attained a maturation rank of dry gas, cracking the previously formed oil. In the Carboniferous and early Permian, the Palaeozoic succession was faulted, tilted and subjected to intensive erosion (Fig. 2). Local Permo-Carbonifereous igneous intrusive rocks occur in the Terne-1 borehole and elsewhere. However, these did not affect the regional maturity related to burial.

In the area of the Terne-1 borehole, subsidence resumed in the Permo-Triassic and maximum reburial probably occurred in Cretaceous to early Palaeogene time as is the general scenario in Denmark (Fig. 2). Modelling suggests that the thermal rank reached during the Palaeozoic was not exceeded during the reburial of the Terne- 1 area. Nevertheless, because of sparse data and modelling uncertainty, we cannot exclude that some shale could have retained hydrocarbongeneration potential throughout the Palaeozoic, and additional hydrocarbons may have formed during the Mesozoic and Cenozoic in some areas.

\section{The geological model for the assessment}

In Denmark only two boreholes outside the Skåne-Bornholm area penetrate the Alum Shale (Slagelse-1 and Terne-1; Fig. 1), hence the prospective area of the Alum Shale was delimited largely without borehole data. The analysis was based on maps of (1) the depth to the base of the Palaeozoic (Lassen \& Thybo 2012), (2) the distribution of Palaeozoic strata (Vejbæk \& Britze 1994) and (3) the regional thickness of the Alum Shale Formation and its subdivisions (updated and somewhat modified from Buchardt et al. 1997). These maps were used to identify areas where the Alum Shale is thicker than $20 \mathrm{~m}$, gas mature and within a current depth interval of $1.5-7 \mathrm{~km}$, which are relevant parameters for gas exploration.

The prospective areas (Fig. 3A) largely follow the margins of the Norwegian-Danish Basin. Alum Shale is most likely also present in the central part of the basin, but the shale is

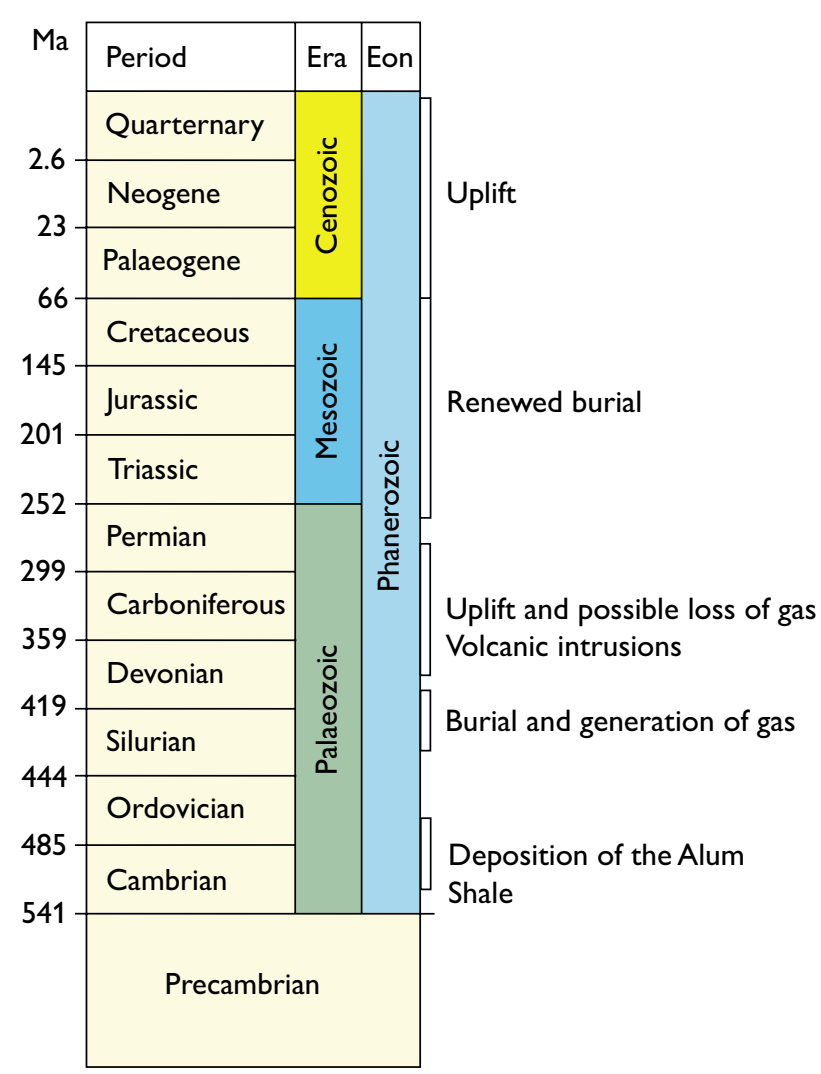

Fig. 2. Timing of main events affecting the gas potential in the Alum Shale in southern Scandinavia.

here buried too deeply for exploration. The Alum Shale thins out or is missing on the Ringkøbing-Fyn High and southwards towards the Caledonian front (Fig. 1).

\section{Sweet-spot mapping within the prospective area}

Exploration undertaken by Shell in Skåne, southern Sweden (boreholes A3, B2 and C3 in Fig. 1), indicates that the Alum Shale Formation, which is now located at $700-800 \mathrm{~m}$ depth, does not contain gas in economically producible quantities and that gas leakage from the shale has increased the risk for a viable gas play (Pool et al. 2012). Reservoir pressure reduction caused by uplift and loss of reservoir integrity due to faulting and fracturing are the likely mechanisms of gas loss. In Skåne the gas may have leaked out through millions of years of uplift and progressive erosion since it formed more than 400 million years ago. In Denmark, in contrast to Skåne, the Palaeozoic shale was reburied in the Mesozoic and thus may retain gas to a greater degree.

Two types of areas with different risks of gas leakage were defined in the geological model, based on the thickness of Palaeozoic strata mapped by Lassen \& Thybo (2012). Preserved thickness is taken as the best indicator for the magnitude of uplift and thus for the risk of reservoir depressurisa- 
Fig. 3. A: Prospective areas in Denmark for gas in the Alum Shale. B: Distribution of sweet spots versus non-sweet spots within the prospective area of Denmark (the term sweet spot is defined in the text). Alum Shale is likely also present in the deeper parts of the Norwegian-Danish Basin, but here it is buried more than $7 \mathrm{~km}$, i.e. too deeply for shale gas exploration with the current costs of drilling.
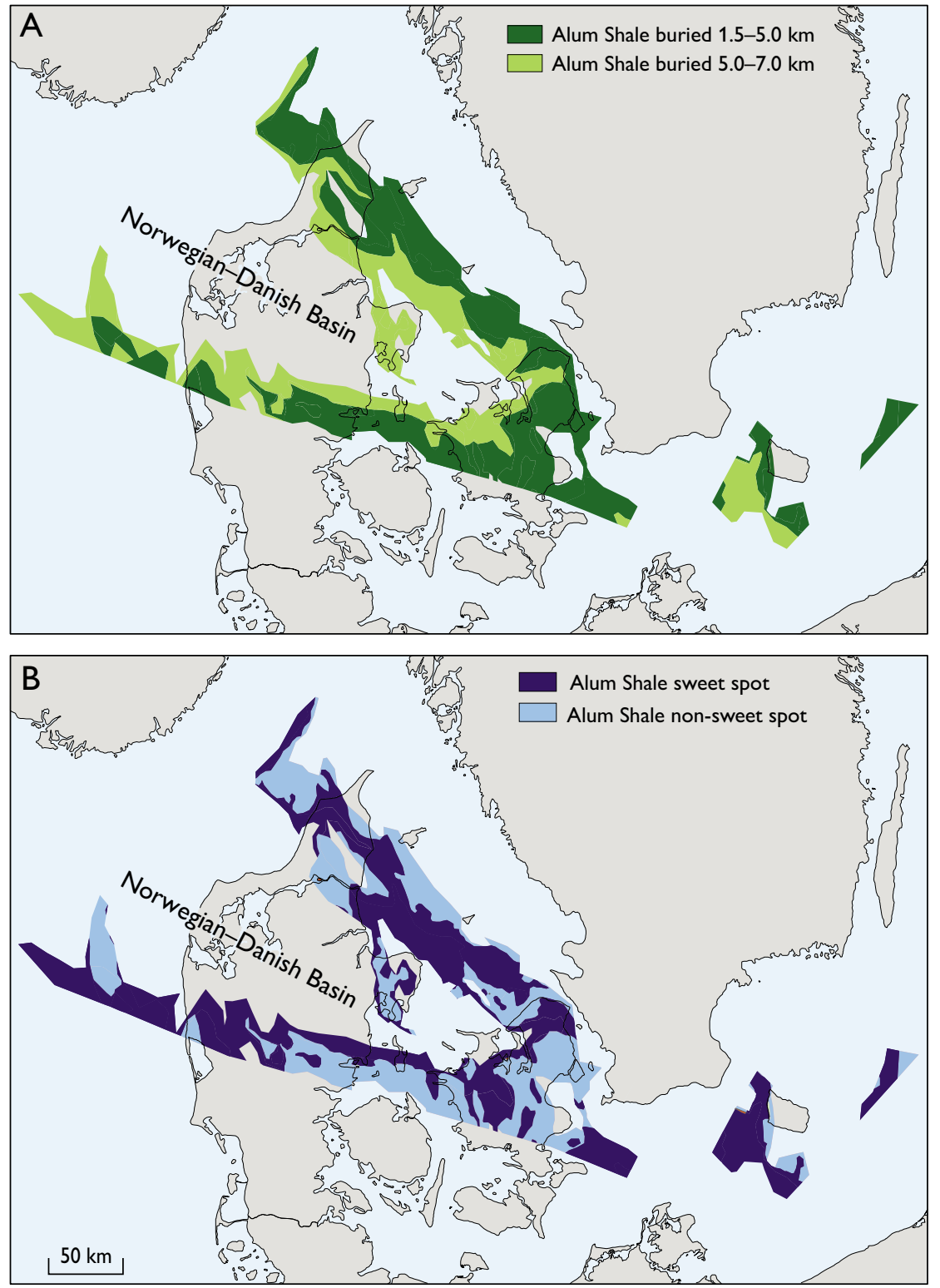

tion in Late Palaeozoic time (Fig. 3B). Accordingly, within the prospective area, 'sweet spots' were defined as fault blocks that contain Alum Shale overlain by more than $1 \mathrm{~km}$ of Palaeozoic strata (e.g. below the blue line in Fig. 4), indicating less intensive Late Palaeozoic uplift and erosion and, hence, greater probability of gas retention (Fig. 4). Where the Alum Shale is overlain by less than $1 \mathrm{~km}$ of Lower Palaeozoic strata, the formation is inferred to have been uplifted to less than $1 \mathrm{~km}$ during the Late Palaeozoic, and those areas are therefore classified as non-sweet spot areas in the assessment.

All the boreholes drilled so far in the Alum Shale in Denmark and Skåne play have been in non-sweet spots as defined here, with the highest reported gas saturation of $20 \%$ (Pool et al. 2012). Hence the quality of sweet spots remains to be tested. The difference in uplift history, and thus potentially in the gas content, is accounted for in the assessment model of Gautier et al. (2013) by adopting different estimated ultimate recovery (EUR) and success ratios for boreholes drilled in sweet spots (average EUR $13.1 \times 10^{6} \mathrm{Nm}^{3}$ gas) versus nonsweet spots (average EUR $6.7 \times 10^{6} \mathrm{Nm}^{3}$ ).

\section{Development strategies}

The USGS assessment methodology assumes unrestricted application of best practice current technology, which in the present case is expected to be horizontal drilling with multistage hydrofracturing. In Denmark the Ordovician-Silurian shale overlying the Alum Shale may constitute a rather thick $(c .300 \mathrm{~m})$ additional interval in which other development strategies may be relevant. This inference is based on 


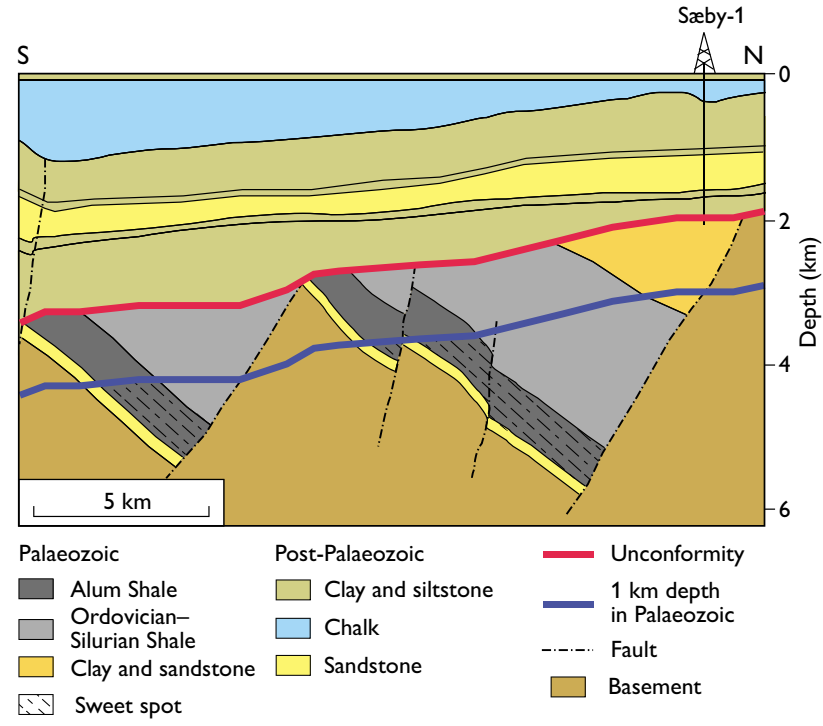

Fig. 4. Conceptual cross section showing the subsurface geology in northern Jylland. The Alum Shale is present in tilted fault blocks below the Caledonian unconformity. Sweet spots are the areas with lowest risk of gas leakage during Late Palaeozoic uplift and are defined as regions where the Alum Shale is overlain by more than $1 \mathrm{~km}$ of Lower Palaeozoic strata. Modified and generalised from Mogensen \& Korstgård (2003).

the Terne-1 borehole where a $250 \mathrm{~m}$ thick shale interval with TOC values of $1-3 \%$ overlies the Alum Shale. These stratigraphic intervals are the targets for exploration in Poland, Lithuania and other countries in the eastern sector of the basin and may constitute an important additional reservoir in Denmark. In addition, a tight gas play in Upper Silurian or Lower Permian sections may also be present in the subsurface of Denmark and might add to the unconventional resource estimate.

\section{Conclusions}

The estimated technically recoverable shale gas resource is comparable to the total volume of gas produced from the Danish part of the North Sea in the period 1972-2011 and twice the amount of remaining reserves of conventional gas in the Danish sector of the North Sea. However, in contrast to the resource estimates for the North Sea, the estimated shale gas resource does not take economic viability into account.
Shale gas exploration in Denmark is in its early stages. This is reflected in the large range of the estimate. It is thus crucial to obtain information from new boreholes, notably from sweet-spot areas, in order to calibrate and constrain the resource estimation model.

The impact on the resource estimate from other development strategies or from additional play intervals and plays is not taken into consideration in the gas resource estimate by Gautier et al. (2013). Whether this is relevant awaits the evaluation of the first Danish exploration borehole to be drilled in the Lower Palaeozoic in northern Jylland.

\section{References}

Buchardt, B., Nielsen, A.T. \& Schovsbo, N.H. 1997: Alun Skiferen i Skandinavien. Geologisk Tidsskrift 1997(3), 1-30.

Gautier, D.L., Charpentier R.R., Gaswirth, S.B., Klett, T.R., Pitman, J.K., Schenk, C.J., Tennyson, M.E. \& Whidden, K.J. 2013: Undiscovered gas resources in the Alum Shale, Denmark. U.S. Geological Survey Fact Sheet 2013-3103, 4 pp.

Lassen, A. \& Thybo, H. 2012: Neoproterozoic and Palaeozoic evolution of SW Scandinavia based on integrated seismic interpretation. Precambrian Research 204-205, 75-104.

Mogensen, T.E. \& Korstgård, J.A. 2003: Triassic and Jurassic transtension along part of the Sorgenfrei-Tornquist Zone, in the Danish Kattegat. In: Ineson, J.R. \& Surlyk, F. (eds): The Jurassic of Denmark and Greenland. Geological Survey of Denmark and Greenland Bulletin 1, 439-458.

Nielsen, A.T. \& Schovsbo, N.H. 2011: The Lower Cambrian of Scandinavia: depositional environment, sequence stratigraphy and palaeogeography. Earth Science Reviews 107, 207-310.

Petersen, H.I., Schovsbo, N.H. \& Nielsen, A.T. 2013: Reflectance measurements of zooclasts and solid bitumen in Lower Palaeozoic shales, southern Scandinavia: correlation to vitrinite reflectance. International Journal of Coal Petrology 114, 1-18.

Pool, W., Geluk, M., Abels, J. \& Tiley, G. 2012: Assessment of an unusual European shale gas play: the Cambro-Ordovician Alum Shale, southern Sweden. Proceedings of the Society of Petroleum Engineers/European Association of Geoscientists and Engineers Unconventional Resources Conference, 20-22 March, 2012, Vienna, 152339.

Schovsbo, N.H., Nielsen, A.T., Klitten, K., Mathiesen, A. \& Rasmussen, P. 2011: Shale gas investigations in Denmark: Lower Palaeozoic shales on Bornholm. Geological Survey of Denmark and Greenland Bulletin 23, 9-12.

Vejbæk, O.V. \& Britze, P. (compilers) 1994: Geological map of Denmark 1:750 000. Top pre-Zechstein (two-way traveltime and depth). Danmarks geologiske Undersøgelse Kortserie 45, 8 pp., 3 maps.

\section{Authors' addresses}

N.H.S, Geological Survey of Denmark and Greenland, Øster Voldgade 10,DK-1350 Copenhagen K, Denmark. E-mail: nsc@geus.dk

A.T.N., Natural History Museum of Denmark, Øster Voldgade 5-7, DK-1350 Copenhagen K, Denmark.

D.L.G., Consulting Geologist, 3954 Nelson Court, Palo Alto, California 94306, USA. 